\title{
Graduate Students' Perception of the Design and Management of Graduate Programs: A Case Study of Egerton University
}

\author{
Mary C. Lopokoiyit \\ Department of Agricultural Education and Extension, \\ P.O. Box 20115-536, Egerton University \\ Email:mclopokoiyi@@yahoo.com \\ Dr. Ronald Chepkilot \\ Kabarak University \\ P.O. Box 20157 Private Bag, Kabarak. \\ Email: rchepkilot@kabarak.ac.ke
}

\section{Doi:10.5901/jesr.2013.v3n3p79}

\section{Abstract}

This study was designed to provide information on the quality of educational programs as perceived by graduate students so as to remain competitive in the provision of higher education. Graduate programs are self-sponsored and students ought to receive value for money, quality teaching and service. Unlike undergraduate students who apply to the Joint Admissions Board $(J A B)$, graduate students choose to enrol at Egerton University and are therefore 'true' customers. A cross-sectional survey design was used and a modified HEdPERF-SERVPERF scale consisting of three dimensions of program design and management was used to collect data. 138 graduate students were sampled and were between 25 and 52 years with a mean of 36.84 years. Females comprised $23.2 \%$ while males were $76.8 \%$. Student loyalty was expressed by $40.6 \%$ of the Graduate students being alumni of Egerton University. Majority of graduate student (79.0 \%) were self-sponsored while $20.3 \%$ had sponsorship from various organizations. A positive perception was obtained for quality of interaction with administrative staff (72.5\%), faculty and department staff (62.3\%). The respondents were dissatisfied with communication on academic and administrative issues at the department and faculty level, lack of feedback, procedures for research, thesis defence schedules and interactions with the finance department. It is recommended that the university, improve communication and management of graduate programs, assist graduate students secure scholarships and train frontline employees on people skills.

Keywords: graduate students; perception; program design; program management

\section{Introduction}

The Kenyan university system is large by African standards with seven government sponsored public universities and seventeen private universities with approximately 80,000 students (CHE, 2006). The Kenya Government spends up to $0.9 \%$ of its GDP on education or KShs. 92.868 billion 2006/2007 financial year of which KShs. 12.784 billion had been earmarked for higher education. Despite these figures, higher education sector is still grossly under funded (Cheboi, 2006). This puts the issue of quality at the forefront of university programs, processes and output. With approximately $45 \%$ of the students enrolled in public universities paying the full tuition fee which is over 10 times the Gross National Income (GNI) per capita (Cheboi, 2006), there is need to ensure that the quality of higher education matches international standards by establishing quality assurance mechanisms both internally and externally in the Universities. Graduate students are part of these self-sponsored students and have specific research and professional development needs that have bearing on their choice of program and University to enrol in. It is important that these students and their families make positive judgments on the benefits to be gained from a degree to justify the high private costs; therefore monitoring feedback from students is an important element of quality assurance and improvement of quality of teaching and learning (Brookes, 2003). It is also expected that Universities demonstrate responsible actions in their professional practices, be accountable for public funds received and demonstrate the results they achieve with the available resources (Jackson, 1998). The increasingly competitive environment in the provision of higher education has also underscored the need to monitor levels of students satisfaction (King, Morison, Reed \& Stachow, 1999).

Soliciting feedback from students on their entire learning experience enables institutions understand better the 
strengths and weaknesses in their policies, practices and procedures and to form the basis for quality enhancement (Jackson, 1996). This enables student views to be integrated into quality enhancement decisions. There is an increasing trend in higher education for institutions to view themselves as competitors leading to mounting pressures for each college and university to provide high quality courses in order to obtain a continuous supply of qualified students seeking entry (Brookes, 2003). Provision of education is a service industry and universities must look beyond product orientation and pay significant attention to customer transactions and employee behaviour. The study therefore sought to determine the perceptions of graduate students toward the quality of interactions to form a basis for continuous improvement and enhancing value to the customer.

\section{Purpose of the Study}

The purpose of this study was to describe the characteristics of graduate students and to determine the graduate students' perception of the quality of educational experiences at Egerton University in order to generate information on the level of student satisfaction with various aspects of teaching and support services.

\section{Objectives of the Study}

The following objectives guided the study.

(i) Describe the characteristics of graduate students enrolled at Egerton University.

(ii) Determine the relationship between the characteristics of graduate students and their perception of the quality of educational experiences.

(iii) Determine differences between Year 1 and Year 2 graduate students' perception of the quality of educational experiences.

\section{Measuring Service Quality in Higher Education}

Parasuraman, Zeifiad and Berry $(1985,1988)$ developed SERVQUAL, a conceptual model of service quality from their work in the area of retail marketing. SERVQUAL is based on the assumption that satisfaction is found in satiations where perceptions of service quality meet or exceed consumer expectations. Perceptions are measured from twenty-two multiitem aspects of service quality to rate each factor's importance (expected service quality). Parasuraman et. al. (1985) identified five dimensions of service quality, Assurance, Empathy, Reliability, Responsiveness, and Tangibles. The SERVQUAL instrument uses four to five items to measure each of these dimensions of service quality often referred to as the Gap model. The SERVQUAL model was later refined to be applicable across a broad spectrum of services (Parasuraman, Zeithaml and Berry, 1990). Cronin and Taylor (1992) developed the model SERVPERF where Service Quality is equated to Performance. The model has five dimensions Responsiveness, Assurance, Empathy, Tangibles and Reliability and comprises 22 items. It is based on perceptions of performance only and it relies on the construct that service quality should be measured as an attitude. SERVPERF was found to be an improvement over SERVQUAL providing more reliable estimations, greater validity, explained variance and less bias than SERVQUAL. It is similar to the SERVQUAL model in its concept of quality and faced similar criticisms that it was too generic and an inadequate instrument to assess perceived quality in higher education. Studies done using SERVPERF therefore have modified the items and added more items to enrich the model and adapt it to higher education (Holdford \& Reinders, (2001); Robbins \& Daniels, (2001).

Firdaus (2005) developed a more comprehensive model HEdPERF (Higher Education PERFormance-only) that attempted to capture the authentic determinants of service quality in higher education. The 41 item instrument had six dimensions; non-academic aspects, academic aspects, reputation, access, programme issues, and understanding. In a study done in Malaysia, Firdaus (2005) found that access was the most important dimension of quality. Access was characterized by aspects such as approachability, ease of contact, availability and convenience. Although Firduas (2005) expanded the concept of quality to non-academic aspects and programme issues the model still follows the basic marketing categorization of quality dimensions as SERVQUAL and SERVPERF and does not adequately reflect the characteristics of an higher educational institution such as teaching and learning, academic engagement and transformative aspects. Higher education involves not only consumption but a transformation of the consumer that ought to be considered when developing models to assess the perception of students. The identification of quality dimensions is particularly important when developing a model for higher education because what is perceived important in one 
country may not be in another, therefore general categories may mask quality parameters that may be important for improving service delivery. This is evident in a further study done to relative efficacy of SERVPERF and HEdPERF (Firdaus, 2006). The study was designed to assess the relative strength of each instrument in order to determine which instrument had superior measurement capability in terms of unidimensionality, reliability, validity and explained variance. HEdPERF outperformed SERVPERF as expected due to the additional quality dimensions specific to higher education. Further analysis of a merged HEdPERF and SERVPERF models to a new modified HEdPERF-SERVPERF scale yielded more reliable estimations, greater explained variance and consequently a better fit. The new HEdPERF-SERVPERF scale had 35 items and four dimensions; non-academic aspects, Academic aspects, Reliability and Empathy. The new scale had a reliability of between 0.77 and 0.91 compared to 0.63 to 0.92 for the HEdPERF scale and 0.68 and 0.76 for the SERVPERF scale. The reduction of quality dimensions to four and relative increase of items per dimensions from the same pool of items resulted in higher reliability scores but similar criterion and construct validity scores as HEdPERF. Although HEdPERF and the new HEdPERF-SERVPERF have improved on the development of a model to assess perceptions of quality in higher education they are rather broad and generic in analysis of service quality for strategic management where it is necessary to identify specific areas for improvement. The study therefore built on these models to develop a more dimensions of quality in higher education.

\section{Quality of Higher Educational Services}

The diverse services and programs offered at universities have resulted in differing, even conflicting perspectives to what constitutes quality performance and service (Lindsay, 1992). Holford and Reinders (2001) argue that educators who rely on SERVQUAL or SERVPERF alone to assess students perceptions of educational quality accept the premise that consumers rely on functional quality to evaluate service quality. However, in higher education the perception of quality is developed over the years of study through a technical, intellectual, participative and a personal process. Quality in higher education conforms to the three characteristics of service that make the determination of quality multidimensional due to the interactive and developmental nature of higher education.

Educational service is:

1. Intangibility:- Services cannot be consumed, measured, tested, stored or verified before being measured,

2. Heterogeneity:- Customers have heterogeneous needs and do not all have the same priorities,

3. Inseparability:- The production and consumption of services cannot be separated as in the case of manufacturing therefore quality can only be determined during and after the rendering of the service (Parasuaman, Zeithami, \& Berry, 2004)

Educational services are first sold, then produced and consumed simultaneously. Students experience the quality of the service while they are receiving it and utilizing it such as lectures, hostels and library. Service performance may vary from day to day, across offices, departments, faculties, and lecturers resulting in variable performance and quality. The study therefore viewed quality as a cumulative perception of graduate students across various dimensions of quality.

Graduate students interact with administrative staff for many reasons. These include paying fees, timetabling, registration, or borrowing books. Administrative staff interacts with students on a day to day basis and play a central role in generating student satisfaction. They are expected to be knowledgeable, helpful and courteous. Berry et. al., (1985) and Bitner et. al., (1990) suggest that frontline employees can significantly influence the degree of satisfaction that customers experience. Holford and Reinders (2001) found that separating teaching and administrative staff reduces unexplained variance and provides better information upon which improvements can be made. Provision of education as a service industry ought to pay significant attention to customer transactions and employee behaviour. The study therefore sought students perceptions on the quality of their interactions with administrative and faculty staff and with teaching staff (lecturers). Institutions have physical structures that provide utilization and aesthetic value evident in the design and location of libraries, lecture theatres, cafeteria, computer laboratories and sporting facilities. In addition to these factors there are also ancillary services such as the availability of parking, quality, cost of meals in the cafeteria, health, banking and counselling services are considered important. Students spend a considerable proportion of their time using these facilities hence, their potential to influence student satisfaction (Mavondo \& Zaman, 2000).

Athiyaman et. al.,(1994) suggest that that reputation, career opportunities, program issues, physical aspects and location as important attributes that contribute towards an excellent university. Athiyaman (1997) places emphasis on library services, computer facilities, recreational activities, class size, difficulty of content, competent staff, student workload and availability of staff for student consultation. These studies enrich the concept of quality higher education from different perspectives and different universities worldwide. From the above review of literature of studies depicting 
quality an educational perspective and from a marketing service orientation the researcher developed eleven dimensions of service to which graduate students gave their perceptions toward the quality of educational experience provided at Egerton University. Each dimension consisted of 8 to 9 items that were adapted from the above literature review and quality models.

(i) Quality of program design and organization

(ii) Quality of interaction with administration staff

(iii) Quality of interactions with departmental and faculty staff

\section{Sampling Procedure and Sample Size}

The total number of graduate students in the target population was 462 at Egerton University and a proposed sample size of 212 was obtained from sample size tables published by Israel (1992) at a confidence level of 95 per cent and $\alpha=$ 0.05. To ensure that the questionnaire were administered to different cohorts of students, the students were sampled using proportional stratified random sampling based on the location of program and across the levels of study i.e. first and second year students. This technique ensured that all subgroups in the population were proportionately and adequately represented (Cohen \& Manion, 1989; Wiersma, 1995).

\section{Data Collection}

The questionnaire also sought to determine the level of graduate student satisfaction with the quality of educational experience. This section consisted of ninety one items on a five point Likert scale was used to indicate the level of perception. The questionnaire also included two open-ended questions soliciting feedback on improvements to educational service and academic program. Participation was voluntary and a response rate of $65.09 \%$ (138 out 212 students) was obtained. There was disparity in return rates across the campuses and the year of study and the returns from the year two graduate students were lower than expected because most students were carrying out their research projects away from the campuses while some had returned to their work stations, therefore the study used the accessible students.

\section{Results and Discussions}

\subsection{Characteristics of Sampled Graduate Students}

The demographic characteristics included in the study included age, gender, qualification and number of years after graduation, academic program enrolled, year of study, campus location, source of finance for study, and employment/source of living. The 138 sampled respondents were aged between 25 and 52 years with a mean age of 36.84 years and a mode of 35 years. The standard deviation was 6.256 implying that ninety five percent of the

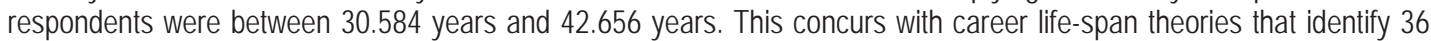
years or 10 to 15 years after initial employment as a critical phase in career development that may result in career stagnation and subsequent decline unless efforts are made to improve through further education. In a review of data summarizing career development and task mastery over 29 years, Jespen and Dickson, (2003) reveal trends that are consistent with life-span theory and that individuals between 25 and 44 years seek to establish their niche in society and in the occupational world resulting in career coping behaviours. These include earning degrees and certifications, receiving support from others, recognition for job performance and advancing in the organization. This age bracket also coincides with the progression from middle level management to senior management that often requires additional technical or professional qualifications. The age distribution is particularly important for the University because the students have substantial experience in the world of work and have specific training needs they expect to be met as they enrol in graduate programs.

Of the sampled students 72.5 percent $(n=100)$ were first years, while only 27.5 percent $(n=38)$ were second years. The difference in the number of students in the two years of studies was attributed to the fact that most of the second year students were not available during the time of the study. Majority of them had started their research projects while others had reported back to their working stations. For the first years, they were still undertaking their course work and thus available in campuses during the time of the study. Out of the 138 students, 106 (76.8\%) were males and 32 $(23.2 \%)$ were female. This was attributed to the general gender imbalance in access and equity to educational 
opportunities in the country. Women are disproportionately represented at the higher levels of education as a result of numerous social, cultural and economic factors compared to their male counterparts. Figure 1 illustrates the composition of students by gender across the campus location.

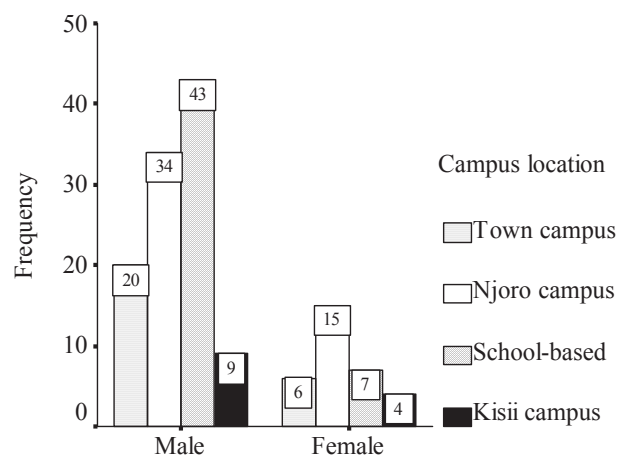

Gender

Figure 1: Gender of graduate students across campus location

All the respondents were Kenyans and 60.1 percent of the respondents were graduates from local universities but of significance is that 40.6 percent of the graduate students were from Egerton University as depicted in Table 3 . This may be an indicator of student loyalty indicating that students were satisfied with the educational experience at the undergraduate level. Customer loyalty is a commitment to buy or repatronize a preferred product or service consistently despite situational influences (Oliver, 1997). Loyal students positively influence teaching quality through active participation and committed behaviour. Therefore student loyalty has become an important strategic theme in higher education because not only are they good advocates of the institution they are an important source of funding through fee payment (Helgesen \& Nesset, 2007).

Table 1: Highest academic institution attended by graduate students

\begin{tabular}{|c|c|c|}
\hline Institution & Frequency & Percent \\
\hline Egerton University & 56 & 40.6 \\
\hline University of Nairobi & 23 & 16.7 \\
\hline Kenyatta University & 19 & 13.8 \\
\hline Moi University & 15 & 10.9 \\
\hline Catholic University Of East Africa & 5 & 3.6 \\
\hline Maseno University & 4 & 2.9 \\
\hline JKUAT & 3 & 2.2 \\
\hline Mombasa Polytechnic & 3 & 2.2 \\
\hline Kenya Polytechnic & 3 & 2.2 \\
\hline KNEC & 3 & 2.2 \\
\hline KTTC & 2 & 1.4 \\
\hline KASNEB & 2 & 1.4 \\
\hline Total & 138 & 100.0 \\
\hline
\end{tabular}

The majority of graduate students $(79.0 \%)$ were paying for their studies on their own while only about 20.3 percent were sponsored by their employers, family relations or had been awarded scholarship. This implies that the graduate students are making personal financial sacrifices to enrol in a graduate program. With a mean age of 35years the majority were not illegible for masters scholarships often pegged at 28 to 32 years. This also challenges the University not only to meet the needs of these students but to give them value for their financial sacrifice. Table 5 provides a summary of the various sources of finance for graduate students.

Table 2: Source of finance for studies of graduate students 


\begin{tabular}{lcc}
\hline \multicolumn{1}{c}{ Source of funding } & Frequency & Percent \\
\hline Self-sponsored & 109 & 79.0 \\
Employer sponsored & 15 & 10.9 \\
Family/parents & 5 & 3.6 \\
Scholarship & 6 & 4.3 \\
HELB & 3 & 2.2 \\
\hline \multicolumn{1}{c}{ Total } & 138 & 100.0 \\
\hline
\end{tabular}

The study also sought to establish the means by which the respondents earned their living. Table 6 shows that 61.6 percent of graduate students are civil servants employed by the Government of Kenya however with the majority being self sponsored implies that a majority of civil servants are not sponsored by the government but to advance in their careers they need to further their studies on their own. This has implications on loyalty and retention of highly qualified civil servants.

Table 3: Means of earning a living by graduate students

\begin{tabular}{lcc}
\hline \multicolumn{1}{c}{ Means } & Frequency & Percent \\
\hline Government employed & 85 & 61.6 \\
Self-employed & 19 & 13.8 \\
Private organization & 18 & 13.0 \\
Parastatal & 12 & 8.7 \\
Unemployed & 4 & 2.9 \\
\hline \multicolumn{1}{c}{ Total } & 138 & 100.0 \\
\hline
\end{tabular}

\subsection{Quality of Program Design and Organization}

Quality of program design and organization was assessed from a series of 8 statements. Table 8 shows the distribution of their responses on the eight statements. The majority of students had a positive perception with the program design in meeting their needs when enrolling in the graduate program with a high mean of 4.32 and a standard deviation of 0.936 .

Table 4: Quality of program design and organization

\begin{tabular}{|c|c|c|c|c|c|c|c|}
\hline \multirow{2}{*}{ Statement } & \multicolumn{5}{|c|}{ Response (\%) } & \multirow[b]{2}{*}{ M } & \multirow[b]{2}{*}{ SD } \\
\hline & SD & D & U & A & SA & & \\
\hline The program is relevant and meets my personal objectives for enrolling in it & 1.4 & 5.1 & 8.7 & 29.7 & 55.1 & 4.32 & 0.936 \\
\hline Lecture hours conveniently scheduled & 10.1 & 13.8 & 13.0 & 31.2 & 31.9 & 3.61 & 1.331 \\
\hline $\begin{array}{l}\text { The academic standards of the work expected of the students to pass was made } \\
\text { clear to me }\end{array}$ & 9.4 & 13.8 & 14.8 & 37.7 & 24.6 & 3.54 & 1.262 \\
\hline Registration requirements and procedures were made clear to me & 10.9 & 12.3 & 26.8 & 31.2 & 18.8 & 3.35 & 1.230 \\
\hline I was given helpful advice when choosing my subjects/units & 18.8 & 15.9 & 23.9 & 24.6 & 16.7 & 3.04 & 1.356 \\
\hline Catalogue and course descriptions are readily available & 22.5 & 19.6 & 23.9 & 17.4 & 16.7 & 2.86 & 1.389 \\
\hline Procedures for research work, defence and fieldwork are readily available & 18.8 & 20.3 & 31.9 & 20.3 & 8.7 & 2.80 & 1.215 \\
\hline Department and faculty defence schedules are easily available & 21.7 & 20.3 & 34.1 & 18.1 & 5.8 & 2.66 & 1.175 \\
\hline
\end{tabular}

$\mathrm{N}=138, \mathrm{M}=$ Means, $\mathrm{SD}=$ Standard deviation

This implies that the graduate academic programs offered at Egerton University are relevant in terms of curriculum design, assessment, curriculum and scheduling of lectures. Aspects of the program design handled by academic staff such as scheduling of lecture hours are often done in consultation with graduate students also had high means. Egerton University has stringent conditions for curriculum design that involves stakeholders after which the programs are vetted by the board of graduate studies and approved by the University Senate. Assessment and academic standards are also established as per the University statutes and upheld by the external examiners hence the high ratings on these items, 3.61 and 3.54. However, the graduate students had a negative perception about the administration and organization of the program especially on basic communication about evidenced by low means $2.86,2.80$ and 2.66 . These are critical 
areas of the program design had low ratings indicating that graduate student dissatisfaction with the administration of the programs rather than the design. The responsibility for program administration and organization falls with the respective departments who in turn work with the respective faculties. These are where graduate students are based during their studies and imply that departments are not responsive to the communication needs of graduate students. This indicates a need for departments and faculties to allocate knowledgeable staff to deal with graduate students administrative and academic information needs. A perception about the quality of program design and organization index score was formed (reliability coefficient, $\alpha=0.6180$ ) and collapsed into three ordinal categories negative, neutral and positive perception. Table 5 summarizes the levels of perception about the quality of the program design and organization.

Table 5: Perception of the quality of the program design and organization

\begin{tabular}{cccc}
\hline Levels of perception & Index score & Frequency & Percent \\
\hline Negative & $8-24$ & 30 & 21.7 \\
Neutral & 24 & 12 & 8.7 \\
Positive & $25-40$ & 96 & 69.6 \\
\hline Total & & 138 & 100.0 \\
\hline
\end{tabular}

Table 9 indicates that 69.6 percent of the respondents had a positive perception about the quality of program design and organization of their graduate studies. This suggests a robust curriculum design and content was considered more important to student expectations of their respective programs and was a reflection of what aspects of program design and organization that they consider of quality.

\subsection{Quality of Interaction with Administrative Staff}

Quality of interaction with administrative staff was assessed from a series of 8 statements. Table 10 shows the distribution of their responses on the eight statements.

Table 6: Quality of interaction with administrative staff

\begin{tabular}{|c|c|c|c|c|c|c|c|}
\hline \multirow{2}{*}{ Statement } & \multicolumn{5}{|c|}{ Response (\%) } & \multirow[b]{2}{*}{ M } & \multirow[b]{2}{*}{ SD } \\
\hline & SD & D & $\mathrm{U}$ & A & SA & & \\
\hline I have experienced gender prejudice by administrative staff & 71.0 & 15.2 & 6.5 & 1.4 & 5.8 & 4.44 & 1.081 \\
\hline I have experienced ethnic or racial prejudice by administrative staff & 71.0 & 10.9 & 11.6 & 2.9 & 3.6 & 4.43 & 1.046 \\
\hline Library staff are courteous and helpful & 8.0 & 5.1 & 24.6 & 34.1 & 28.3 & 3.70 & 1.169 \\
\hline Administrative staff treat me with respect & 10.9 & 7.2 & 31.9 & 26.8 & 23.2 & 3.44 & 1.232 \\
\hline Graduate school staff were helpful during orientation week & 13.8 & 17.4 & 18.1 & 24.6 & 26.1 & 3.32 & 1.388 \\
\hline Secretarial staff are courteous and helpful & 14.5 & 9.4 & 28.3 & 30.4 & 17.4 & 3.27 & 1.270 \\
\hline Admissions office staff were courteous and willing to help during orientation week & 14.5 & 16.7 & 21.0 & 26.1 & 21.7 & 3.24 & 1.354 \\
\hline The finance office staff are courteous and helpful & 18.8 & 21.0 & 20.3 & 26.1 & 13.8 & 2.95 & 1.336 \\
\hline
\end{tabular}

Graduate students have a positive perception of the quality of interaction with administrative staff at Egerton University. The lower ratings associated with the finance office may be attributed to the fact that the majority of graduate students are self-sponsored and may have had difficulties in meeting fee payments resulting in unpleasant interactions with the rigid requirements of the finance department. This may require that the University assist students secure partial or full scholarships. These findings support a study by Mavondo and Zaman (2000) which indicated that students found it difficulty in dealing with administrative staff and were dissatisfied however the results were not statistically significant. The study findings concur with Berry et al. (1985) and Bitner et al. (1990) findings that frontline employees can significantly influence the degree of satisfaction that customers experience as depicted in Table 11 where 72.5 percent of the respondents had a positive perception about the quality of interaction with administrative staff responsible for their graduate studies. This suggests that graduate students learn in a secure environment free from gender or ethnic prejudice and that administrative staff in the departments, faculty and library are courteous and treat graduate students with respect. A perception about the quality of interaction with administrative staff is presented Table 7. 
Table 7: Levels of perception of the quality of interaction with administrative staff

\begin{tabular}{cccc}
\hline Levels of perception & Index score & Frequency & Percent \\
\hline Negative & $8-24$ & 27 & 19.6 \\
Neutral & 24 & 11 & 8.0 \\
Positive & $25-40$ & 100 & 72.5 \\
\hline Total & & 138 & 100.0 \\
\hline
\end{tabular}

Source: Research Data

\subsection{Quality of Interaction with Department and Faculty Staff}

Quality of interaction with department and faculty staff was assessed from a series of 8 statements. Table 8 shows the distribution of their responses on the eight statements. Senior administrative and academic staff deal with graduate students on a day to day basis in the course of their studies. These are critical interactions that can make learning difficult or a pleasant experience. Acceptance, respect, courteousness are soft people skills that are important in dealing with older, mature students and was found to be acceptable with means between 3.61 and 4.50 . However more can be done to sensitize staff on their impact on the quality of educational experience. The statements with low mean rating involve information communication on academic and administrative issues at the department and faculty levels that indicate dissatisfaction. This is further compounded with a lack of communication or feedback mechanism at the department level to deal with graduate student concerns with a mean of 2.72 . This is particularly important when dealing with the processing of examinations, transcripts that provide information on academic progress, mean 2.78 implying that graduate students are dissatisfied with information flow at the department and faculty levels that ought to be adequate and timely. Despite these shortcomings faculty and department interactions were cordial and provide an environment free of ethnic or racial prejudice.

Table 8: Quality of interaction with department and faculty staff

\begin{tabular}{|c|c|c|c|c|c|c|c|}
\hline \multirow{2}{*}{ Statement } & \multicolumn{5}{|c|}{ Response (\%) } & \multirow[b]{2}{*}{ M } & \multirow[b]{2}{*}{ SD } \\
\hline & SD & D & $\mathrm{U}$ & A & SA & & \\
\hline I have experienced gender prejudice by department and/or faculty staff & 68.8 & 16.7 & 11.7 & 1.4 & 1.4 & 4.50 & 0.865 \\
\hline I have experienced ethnic or racial prejudice by department and/or faculty staff & 65.2 & 15.9 & 3.6 & 13.8 & 1.4 & 4.30 & 1.136 \\
\hline The department and faculty staff treat me with respect & 5.8 & 15.2 & 21.0 & 28.3 & 29.7 & 3.61 & 1.223 \\
\hline The department and faculty staff are sensitive to student confidentiality & 7.2 & 6.5 & 37.7 & 31.2 & 17.4 & 3.45 & 1.081 \\
\hline Department and faculty staff were helpful during induction week & 10.9 & 23.9 & 21.9 & 23.3 & 20.3 & 3.18 & 1.303 \\
\hline $\begin{array}{l}\text { I receive adequate information on administrative and academic issues from the } \\
\text { department/faculty }\end{array}$ & 19.6 & 21.0 & 26.8 & 21.7 & 10.9 & 2.83 & 1.276 \\
\hline $\begin{array}{l}\text { I receive adequate information on academic progress from the } \\
\text { department/faculty }\end{array}$ & 25.4 & 21.0 & 19.6 & 18.8 & 15.2 & 2.78 & 1.409 \\
\hline The department is responsive to student input and suggestions to the program & 21.7 & 24.6 & 25.4 & 15.9 & 12.3 & 2.72 & 1.306 \\
\hline
\end{tabular}

Table 14 presents the perception of students' assessment with various aspects of their interactions with faculty and department staff. This contributed to the overall positive perception of the quality of interactions with department and faculty staff as depicted in Table 13 that 62.3 percent of the respondents had a positive perception about the quality of interaction with department and faculty staff responsible for their graduate studies. A perception about the quality of interaction with department and faculty staff is summarized in Table

Table 9: Perception of the quality of interaction with department and faculty staff 


\begin{tabular}{cccc}
\hline Levels of perception & Index score & Frequency & Percent \\
\hline Negative & $8-24$ & 39 & 28.3 \\
Neutral & 24 & 13 & 9.4 \\
Positive & $25-40$ & 86 & 62.3 \\
\hline Total & & 138 & 100.0 \\
\hline
\end{tabular}

The percentage of graduate students with a negative perception is close to 30 percent and their sentiments could be attributed to the importance attached to communication of academic and administrative issues at the department and faculty level.

\section{Conclusions and Recommendations}

Graduate students had a positive perception about the overall quality graduate programs and interaction with academic and administrative staff. However, they varied in their perceptions about specific dimensions of interactions. Graduate students were least satisfied by interaction with administrative staff especially finance department staff. Universities should consider providing scholarships, work study programmes or graduate assistantship programs to ease the financial cost of graduate studies. Communication to graduate students also need to be improved. Timely feedback on academic achievement, thesis requirements and supervision ought to be streamlined. Graduate students were satisfied with the academic program design, content and relevance. Communication with faculty and departmental staff need to be improved by providing clear times for consultation and feedback timelines with graduate students. This could be done by developing a workplan with graduate students with clear obligations of both the academic staff and graduate student. The use of telecommunications and internet based communication modes should be embraced. Frontline staff in at the department and faculty need to be sensitized on customer care and communication of mature graduate students.

\section{References}

Athiyaman, A and O'Donnell, B (1994) "Exploring Graduates' Perceptions of the Quality of Higher Education", Journal of Institutional Research in Australasia, 3, (1): 1-7.

Berry, L. L., Zeithaml,V. A., \& A. Parasuraman, A. (1985), "Quality counts in services too", Business Horizons, May-June: 44-52.

Bitner, M. J., Booms, B. M., \& Tetreault, M. I. (1990), "The Service encounter: diagnosing favourable and unfavourable incidents", Journal of Marketing, 54(1):71-84.

Bitzer, E. (2005). Informing a Holistic Approach to Teaching and Learning: Assessing Students' Perceptions of their own Development, University of Stellenbosch, Stellenbosch, South Africa

Borg, W.R \& Gall, D. M. (1989). Educational research. An Introduction $5^{\text {th }}$ Edition Longman Publishers.

Brookes, M. (2003). Evaluating the 'Student Experience': An Approach to Managing and Enhancing Quality in Higher Education. Journal of Hospitality, Leisure, Sport \& Tourism. 2 (1): 17-26

Cheboi, B. C. (2006). Funding Patterns and Their Effects on Quality of Higher Education in Kenya. A Paper Presented at the Regional East Africa Unistaff Alumni Network, on Quality Assurance In Higher Education. Kenyatta University, Nairobi, 6th-10th November, 2006. Unpublished paper Commission of Higher Education (2006). The Fourth Exhibition by Kenyan universities Exhibition Catalogue.

Cohen, L. \& Manion, L. (1989). Research Methods in Education. 3rd Edition, Routledge, London.

Firdaus, A. (2005). The development of HEdPERF: a new instrument of service quality for higher education. International Journal of Consumer Studies.

Firdaus, A. (2006). Measuring service quality in higher education: HEdPERF Firdaus, A. (2006). Measuring service quality in higher education: HEdPERF versus SERVPERF. Marketing Intelligence and Planning. 24 (1): 31-47

Helgensen, O., \& Nesset, E. (2007). What accounts for student's loyalty? Some field evidence. International Journal of Educational Management. 21 (2): 126-143.

Holdford, D., \& Reinders, T. P. (2001). Development of an Instrument to Assess Student Perceptions of the Quality of Pharmaceutical Education. Amarican Journal of Pharmaceutical Education. 65, 125-131

Jespen, D. A., \& Dickson, G. L. (2003). Continuity in Life-Span Career Development: Career Exploration as a Precursor to Career Establishment, http://findarticles.com/p/search.retrieved on 16 September, 2007.

King, M., Morison, I., Reed, G., \& Stachow, G. (1999). Student Feedback Systems in the Business School: A Departmental Model. Quality Assurance in Education. 7 (2): 90-100.

Mavondo, F., \& Zaman, M. (2000). Student Satisfaction With Tertiary Institution and Recommending it to Prospective Students. Visionary Marketing for the $21^{\text {st }}$ Century: Facing the Challenge. ANZMAC

Oliver, R.L. (1997). Satisfaction: A Behavioural Perspective on the Customer. McGraw-Hill, New York, NY. 
ISSN: 2239-978X

E-ISSN: 2240-0524
Journal of Educational and Social Research MCSER Publishing, Rome-Italy
Vol. 3 No. 3

September 2013

Robbins, K. \& Daniels, K. (2001). Benchmarking Reference Desk Service in Academic Health Science Libraries: A Preliminary Survey. College and Research Libraries, July, pp.348-353

Wiersma, W. (1995). Research Methods in Education. An Introduction. 6 $6^{\text {th }}$ Edition, Allyn and Bacon, Needham Heights, Massachusetts. 